Sains Malaysiana 46(9)(2017): 1597-1602

http://dx.doi.org/10.17576/jsm-2017-4609-31

\title{
The Effect of Smartphone's Radiation Frequency and Exposure Duration on NADPH Oxidase 5 (NOX5) Level in Sperm Parameters
}

(Kesan Frekuensi Radiasi Telefon Pintar dan Tempoh Pendedahan ke atas Peringkat NADPH

Oksidase 5 (NOX5) dalam Parameter Sperma)

\begin{abstract}
NorAZURASHIma JAMALUdin*, SYAWAL Shafie AbDUl RAZAK, FARAH HANAN FATHIHAH JAFFAR,
\end{abstract} KHAIRUL OSMAN \& SITI FATIMAH IBRAHIM

\begin{abstract}
Health hazard through smart phone radiation has been associated with male infertility. The suspected prime mediator is the NOX5 enzyme. When activated, the additional pathway for free radical production will damage sperm's DNA. However, conclusive evidence is still lacking. Thus, this study was conducted to comprehend the detrimental effect of the radiation towards sperm parameters by using rat as a model. Parameters measured include sperm concentration, viability, DNA damage status and NOX5 level on sperm. This study consisted of two phases. The first phase was conducted to determine the optimal radiation frequency emitted from the smart phone. The radiation frequencies that were evaluated were $0 \mathrm{MHz}$ (control), $4200 \mathrm{MHz}$ without multiple connection mode (minimum frequency) and $9700 \mathrm{MHZ}$ with multiple connection modes (maximum frequency). Each exposure setting represented one group. Each group consists of eight rats, which received exposure for 6 h/day for two consecutive weeks. All parameters measured showed significant differences. Optimum frequency for significant changes to sperm parameters were identified as the minimum frequency. Second part of the research involved the determination of optimum exposure duration. The optimal frequency obtained was used in combination with exposure duration of $0 \mathrm{~h}$ (control), 2, 4 and $6 \mathrm{~h}$. Each group had 8 rats and exposure was conducted for 2 weeks. The results showed a significant difference for all parameters following $4 \mathrm{~h}$ of exposure. Following this, evaluation of DNA damage status through NOX5 activity was done by using the optimum setting where $0 \mathrm{MHz} / 0 \mathrm{~h}$ as a control and $4200 \mathrm{MHz} / 4 \mathrm{~h}$ per day for up to 2 weeks. The results showed significant differences of Nox 5 fluorescent intensity between the two groups. In conclusion, although smart phone emitted low radiation, it can decrease sperm concentration, viability and increase DNA damage through ROS production. NOX5 pathway has been proven to be the likely pathway of ROS induced RF-EMW.
\end{abstract}

Keywords: DNA damage; sperm concentration; smart phone; NOX5; viability

\section{ABSTRAK}

Bahaya kesihatan melalui radiasi telefon pintar telah dikaitkan dengan ketidaksuburan lelaki. Pengantara utama yang terlibat adalah NOX5, enzim yang mungkin menjadi tapak jalan tambahan dalam pengeluaran radikal bebas yang merosakkan DNA sperma. Walau bagaimanapun, bukti kukuh masih tidak mencukupi. Oleh itu, kajian ini dijalankan untuk memahami kesan buruk radiasi terhadap parameter sperma dengan menggunakan tikus sebagai model.Parameter yang diukur adalah termasuk kepekatan sperma, viabiliti, status kerosakan DNA dan aktiviti NOX5 pada spermatozoa. Kajian ini terdiri daripada dua fasa. Fasa pertama dijalankan untuk menentukan frekuensi optimum yang dipancarkan daripada telefon pintar. Frekuensi radiasi yang dinilai ialah $0 \mathrm{MHz}$ (kawalan), $4200 \mathrm{MHz}$ tanpa mod berbilang sambungan (frekuensi minimum) dan 9700 MHZ dengan mod sambungan pelbagai (frekuensi maksimum). Setiap frekuensi mewakili satu kumpulan. Setiap kumpulan terdiri daripada lapan tikus dengan pendedahan dilakukan selama 6 jam/hari selama dua minggu berturut-turut. Semua parameter yang diukur menunjukkan perbezaan yang signifikan antara kumpulan. Frekuensi optimum yang diperoleh adalah frekuensi minimum. Fasa kedua bagi kajian ini adalah menentukan masa pendedahan optimum. Frekuensi optimum yang diperoleh sebelumnya didedahkan menggunakan sela masa 0 jam (kawalan), 2, 4 dan 6 jam. Setiap kumpulan mempunyai 8 tikus dan pendedahan telah dilakukan selama 2 minggu. Hasil menunjukkan terdapat perbezaan yang signifikan bagi semua parameter selepas pendedahan selama 4 jam. Berikutan itu, penilaian status kerosakan DNA melalui aktiviti NOX5 telah dilakukan dengan menggunakan frekuensi optimum dengan 0 MHz/O jam sebagai kawalan dan 4200 MHz/4 jam setiap hari sehingga 2 minggu. Hasil kajian menunjukkan terdapat perbezaan aktiviti NOX5 yang signifikan antara kedua-dua kumpulan. Kesimpulannya, walaupun telefon pintar memancarkan radiasi yang rendah, ia boleh mengurangkan kepekatan sperma, kebolehhidupan dan meningkatkan kerosakan DNA melalui penghasilan ROS. Tapak jalan NOX5 terbukti sebagai punca penghasilan ROS teraruh RF-EMW.

Kata kunci: Kebolehhidupan; kepekatan sperma; kerosakan DNA; NOX5; telefon pintar 


\section{INTRODUCTION}

Ownership of cell phones in Malaysia has increased from 12,316,788 to 43.248 million units in 2004 to 2014, respectively (Malaysian Communications and Multimedia Commission 2015). Due to the increase use of cell phones, medical practitioners have started to raise concern about the dangers of radiation emitted by the aforementioned units (Falzone et al.2011). Each mobile phone units emits radio frequency magnetic wave (RF-EMW) that is supposed to be fixed and controlled. But due to their multiple connection mode capability (Wi-Fi, Bluetooth, 3G, 2G and GPRS), the RF-EMW can increase along with specific absorption rate (SAR). High SAR causes tissue heating and has been known to cause behavioral changes in mice, rats, monkeys and importantly human beings (IEEE 2006).

Recently, RF-EMW emitted from cell phone had been reported to cause reduction in male fertilizing potential. It is suspected that this occurs through alteration of sperm parameter, reduction in epididymal sperm concentration and direct tissue injury to testis (Agarwal et al. 2008; De Iuliis et al. 2009; Dkhil et al. 2011). Recent study have also showed significant reduction in rat sperm parameters particularly in motility, viability, spermatogenesis, maturation and lipid peroxidation parameters (Meo et al. 2011; Yan et al. 2007).

The pathway on possibility of RF-EMW affecting sperm quality is still unclear. Reactive oxygen species (ROS) is said to be the possible cause. This idea is further extended through a postulation that the excess ROS is generated from a phenomenon known as NADPH Oxidase 5 (NOX5) induced RF-EMW (De Iuliis et al. 2009). NOX5 is an enzyme system that acts as the main source of ROS in sperm (Ghani et al 2012). Thus, we postulate that RF-EMW induces NOX5 production and eventually produces excess ROS. This leads to sperm DNA damage. Based on the above postulation, this study had focus on the effect of RF-EMW and its effect to sperm DNA damage through the NOX5 pathway.

\section{MATERIALS AND METHODS}

\section{ANIMAL}

Animal research protocols for this study was approved by Universiti Kebangsaan Malaysia Animal Ethic Committee (UKMAEC) PP/FISIO/2014/FATIMAH/22-JAN/569-FEB.2014-FEB.-2015. A total of 72 male Sprague Dawley rats weighing 200- $250 \mathrm{~g}$ were supplied by the Animal House, Universiti Kebangsaan Malaysia (UKM). The rats were individually housed in a plastic cage at the Department of Physiology animal room (air-conditioned 24-h, 12-h light and 12- $\mathrm{h}$ dark) and fed with pellets and drank ad libitum. This research was divided into three main experiments.

Experiment 1 This experiment was to determine the optimal RF-EMW frequency. Optimal RF-EMW frequency was defined as the lowest RF-EMW frequency that can cause significant damage to DNA. 24 rats were divided equally into three groups (8/group), one control and two test groups. The rats were placed in individual plastic holder for $6 \mathrm{~h}$ per day for 14 days. The control group was not subjected to any form of RF-EMW frequency. The test groups were exposed to RF-EMW frequency through 2 mobile phones labeled as A (UMTS $2100 \mathrm{MHz}$, GSM 900, 1800, $1900 \mathrm{MHz}$ ) and B (GSM 850/900/1800/1900/WCDMA 900/2100/UMTS $900 / 2100 \mathrm{MHz}$ ). Test group 1 was exposed to both mobile phones without any multiple connection mode capability. This group was labeled as the group receiving minimum frequency (4200 MHz) of radiation. While, test group 2 was exposed to both mobile phones (9700 MHz) with multiple connection mode capability (wireless internet (Wi-Fi), Bluetooth and mobile internet). This group was labeled as maximum frequency. We chose these frequencies because previous studies had never differentiated the frequencies with or without multiple connection mode capability.

Experiment 2 The second experiment involved 32 rats and was divided equally into four groups (8/group) consisting of one control and three test groups. The objective of this experiment was to determine optimal time of exposure. Optimal time of exposure was defined as the lowest time of exposure that can cause significant DNA damage. The control group was not subjected to any RF-EMW frequency. Each rat from the test groups were placed in individual plastic holder and exposed to the previously identified optimal RF-EMW frequency (4200 MHz). The difference between the groups was the exposure time. Group 1 was exposed for $2 \mathrm{~h}$, group 2- (4 h) and group 3- $(6 \mathrm{~h})$ per day for 14 days. We chose $6 \mathrm{~h}$ as the maximum battery usage for both phones.

Experiment 3 The third experiment had involved 16 rats divided equally into two groups (8/group) - control and test group. The objective of this phase was to determine NOX5 activity between control and test group. Again, the control group was not subjected to any RF-EMW frequency while each rat in test group was placed in individual plastic holder and exposed to the optimal RF-EMW frequency (4200 MHZ) and optimal time of exposure (4 h). Both specifications were obtained from the previous two experiments mentioned before. Later, all rats were killed through intravenous anesthesia using Ketamine Xylazil (Animal House, UKM) and sacrificed using cardiac puncture $24 \mathrm{~h}$ after the last RF-EMW frequency. Sperm samples were taken from the rats' cauda epididymis and vas deference using a 'swim up' process (Varisli et. al 2010).

\section{PARAMETERS}

Sperm concentration $10 \mu \mathrm{L}$ of sperm sample was pipetted and placed on MaklerR Counting Chamber. Sperm were counted under a light microscope using $\times 200$ magnification.

Viability A volume of $10 \mu \mathrm{L}$ sperm sample was mixed with $100 \mu \mathrm{L}$ HOST solution and incubated using water 
bath for $45 \mathrm{~min}$ at $37^{\circ} \mathrm{C} .10 \mu \mathrm{L}$ of the mixed solution was then smeared on a glass slide and left to dry. Each sample was duplicated. Then, the slides were dyed in sequence, starting with Diff-Quick Fix, Diff-Quick I and eventually Diff-Quick II. Each step had taken 5 min. The slides were later washed with distilled water to discard excess stain. 200 sperm cells were then counted under light microscope using $\times 200$ magnifications. Viable sperm was as observed with its tail stained. The stained tail appeared curved, thickened or shortened. On the other hand, non-viable sperm's tail appeared straight and unstained.

DNA damage (Neutral comet assay) First layer containing $200 \mu \mathrm{L}$ of $1 \%$ NMA was placed onto a fully frosted slide (StatLab Medical Product Inc., Texas) and covered by clear cover slip immediately before freezing. Later, the slides were placed on ice for $15 \mathrm{~min}$ to complete the freezing process. Cover slip was then removed carefully. Second layer gel was then applied. A volume of $100 \mu \mathrm{L}$ LMA was mixed with $100 \mu \mathrm{L}$ of sperm sample (50:50). $50 \mu \mathrm{L}$ of the mixture was placed over the first layer of agar and covered with clear cover slip immediately before freezing to obtain a homogenous thin layer surface. Then, the slides were placed on ice again for $15 \mathrm{~min}$ to complete the freezing process. Once the gel had hardened, the cover slip was removed carefully. Each sample was done in duplicate. The slides were then transferred into first lysis buffer at $4^{\circ} \mathrm{C}$ for $1 \mathrm{~h}$, immersed in a second lysis buffer at $39^{\circ} \mathrm{C}$ overnight. The next day, the slides were rinsed 3 times $/ 20$ min in distilled water. The slides were then placed into an electrophoresis unit containing electrophoresis buffer and incubated for $20 \mathrm{~min}$. Electrophoresis was run at $25 \mathrm{~V}$ and $300 \mathrm{~mA}$ for $20 \mathrm{~min}$. After electrophoresis, the slides were moved into neutral buffer 3 times, each time for 20 min. A volume of $50 \mu \mathrm{L} / \mathrm{mL}$ Syber Green solution was dripped onto the slide and covered by clear coverslip. 100 comet images for each slide were analyzed using Inverted Fluorescent Microscope (Axiovert 200M, Carl Zeiss, Germany) under $\times 200$ magnification and recorded using AxioCam MRm camera (Carls Zeiss, Germany). All of the images were analyzed using the Comet Assay Software Project (CASP) 1.2.2. Comet parameters collected were tail moment and olive tail moment.

Immunocytochemistry localization $100 \mu \mathrm{L}$ sperm sample was permeabilised in $95 \%$ methanol for $5 \mathrm{~min}$. The mixture was centrifuged $300 \mathrm{~g}$ for $8 \mathrm{~min}$, re-suspended into PBS solution and washed twice. Then, the supernatant was blocked with PBS 5\% BSA for $1 \mathrm{~h}$. Then, the sample was mixed with 1:200 rabbit anti-human NOX5 dilution (HPA019362; Sigma Aldrich, Oakville Canada) and incubated in $4^{\circ} \mathrm{C}$ overnight. Then, the sample was washed with PBS solution at $300 \mathrm{~g}$ for $5 \mathrm{~min}$ and re-suspended in PBS 5\% BSA. Next, 1: 100 FITC- conjugated goat anti-rabbit IgG (HPA019362, Sigma-Aldrich, Oakville Canada) was added to the sample and incubated at $37^{\circ} \mathrm{C}$ for one $\mathrm{h}$. The mixture was then washed in PBS twice. Finally, the supernatant was suspended in $100 \mu \mathrm{L}$ of PBS. $50 \mu \mathrm{L}$ suspensions was mounted on a slide and covered by clear coverslip. All procedures for each sample were duplicated. 100 fluorescent images recorded using fluorescent microscope (Axiovert 200M, Carl Zeiss, Germany) were analyzed using the Image $\mathbf{J}$ software. The parameters collected were fluorescent intensity on acrosome, equatorial, post acrosome, body and tail of the sperm. CTCF (corrected total cell fluorescent) was calculated based on integrated density - (Area of selected cell $\times$ mean fluorescence of background readings).

\section{STATISTICAL ANALYSIS}

IBM SPSS Statistic 20 was used to analyze the result. Statistical test used were ANOVA and Independent T-Test. All values were stated in Mean \pm SEM. The values were considered statistically significant when $p<0.05$.

\section{RESULTS}

Experiment 1: Based on Table 1, minimum and maximum frequency groups were significantly different from control group $(p<0.01)$. Both frequencies showed decrease in sperm concentration and viability, but the maximum frequency had produced a more severe impact. Sperm DNA damage (mean tail moment and mean olive tail moment) were also significantly different between minimum and maximum frequency group compared to the control group. We can conclude that the sperm DNA damage had increased when higher electromagnetic radiation strength was given. Minimum frequency was the optimal frequency as his was when DNA damage started to occur statistically significantly.

Experiment 2 In reference to Table 2, there was significant difference between test groups 2 and 3 to control group while test group 1 showed no significant difference compared to control group. The DNA damage also showed the same result based on mean tail moment and mean olive tail moment. Groups 2 and 3 were significantly different from control group while test Group 1 showed no significant different compared to control group. It can be concluded that sperm concentration, viability and DNA damage started to occur at hour 4 . Thus, hour 4 was considered as the optimal time of exposure.

Experiment 3 Based on Figure 1, there was significantly different between the test group and control group. The result showed that NOX5 activity was significantly higher in test group compared to control group.

\section{DISCUSSION}

Our study on RF-EMW exposure had conclusively shown that reduction of sperm concentration and viability was likely caused by the increase in RF-EMW exposure. We further noticed that the DNA damage increased proportionally to 
TABLE 1. Electromagnetic radiation strength towards (1) sperm concentration, (2) sperm viability, (3) sperm DNA damage mean tail moment and (4) sperm DNA damage mean olive tail moment

\begin{tabular}{lccc}
\hline $\begin{array}{l}\text { Control }(0 \mathrm{MHz}), \\
\text { statistical result }\end{array}$ & $\begin{array}{c}\text { Group } \\
(8 / \text { group })\end{array}$ & $\begin{array}{c}\text { Minimum frequency } \\
(4200 \mathrm{MHz} \text { without any multiple } \\
\text { connection mode capability) }\end{array}$ & $\begin{array}{c}\text { Maximum frequency } \\
(9700 \text { MHz with multiple } \\
\text { connection mode capability })\end{array}$ \\
\hline $\begin{array}{l}\text { Sperm concentration, } \mathrm{F}(3,28)=117, \\
p<0.01\end{array}$ & $6.43 \pm 0.08$ & $* 5.11 \pm 0.04$ & $* 3.41 \pm 0.20$ \\
$\begin{array}{l}\text { Sperm viability, F }(2,21)=14,849, \\
p<0.01\end{array}$ & $189 \pm 0.77$ & $* 103 \pm 0.88$ & $* 8.00 \pm 0.54$ \\
$\begin{array}{l}\text { Sperm DNA damage mean tail } \\
\text { moment, } \mathrm{F}(2,2395)=16,789, p<0.01\end{array}$ & $0.00 \pm 0.00$ & $* 15.33 \pm 0.08$ & $* 13.67 \pm 0.18$ \\
$\begin{array}{l}\text { Sperm DNA damage mean olive tail } \\
\text { moment, } \mathrm{F}(2,2395)=20,340, p<0.01\end{array}$ & $0.00 \pm 0.00$ & $* 58.55 \pm 0.39$ & $* 52.51 \pm 0.48$ \\
\hline
\end{tabular}

*indicates significant difference with control group $(p<0.01, n=8)$

TABLE 2. Time of exposure towards (1) sperm concentration, (2) sperm viability, (3) sperm DNA damage mean tail moment and (4) sperm DNA damage mean olive tail moment

\begin{tabular}{lcccc}
\hline Group (8/group), statistical result & $\begin{array}{c}\text { Control } \\
(0 \mathrm{MHz} / 0 \mathrm{~h})\end{array}$ & $\begin{array}{c}\text { Test Group 1 } \\
(4200 \mathrm{MHz} / 2 \mathrm{~h})\end{array}$ & $\begin{array}{c}\text { Test Group 2 } \\
(4200 \mathrm{MHz} / 4 \mathrm{~h})\end{array}$ & $\begin{array}{c}\text { Test Group 3 } \\
(4200 \mathrm{MHz} / 6 \mathrm{~h})\end{array}$ \\
\hline $\begin{array}{l}\left.\text { Sperm concentration } 10^{5} \text { (mean } \pm \text { SEM }\right), \\
\mathrm{F}(3,28)=117, p<0.01\end{array}$ & $6.40 \pm 0.08$ & $6.30 \pm 0.05$ & $* 5.70 \pm 0.04$ & $* 5.10 \pm 0.04$ \\
$\begin{array}{l}\text { Sperm viability }(\text { mean } \pm \text { SEM), } \\
\text { F }(3,28)=1713, p<0.01\end{array}$ & $189.00 \pm 0.77$ & $189.00 \pm 0.45$ & $* 163.00 \pm 1.51$ & $* 103.00 \pm 0.88$ \\
$\begin{array}{l}\text { Mean tail moment }(\text { mean } \pm \text { SEM), } \\
\text { F }(3,3195)=20927, p<0.01\end{array}$ & $0.00 \pm 0.00$ & $0.04 \pm 0.02$ & $* 2.67 \pm 0.06$ & $* 15.33 \pm 0.08$ \\
$\begin{array}{l}\text { Mean olive tail moment (mean } \pm \text { SEM), } \\
\text { F }(3,3195)=18525, p<0.01\end{array}$ & $0.00 \pm 0.00$ & $0.23 \pm 0.00$ & $* 2.17 \pm 0.05$ & $* 13.50 \pm 0.08$ \\
\hline
\end{tabular}

* Indicate significant difference with control group $(p<0.01, n=8)$

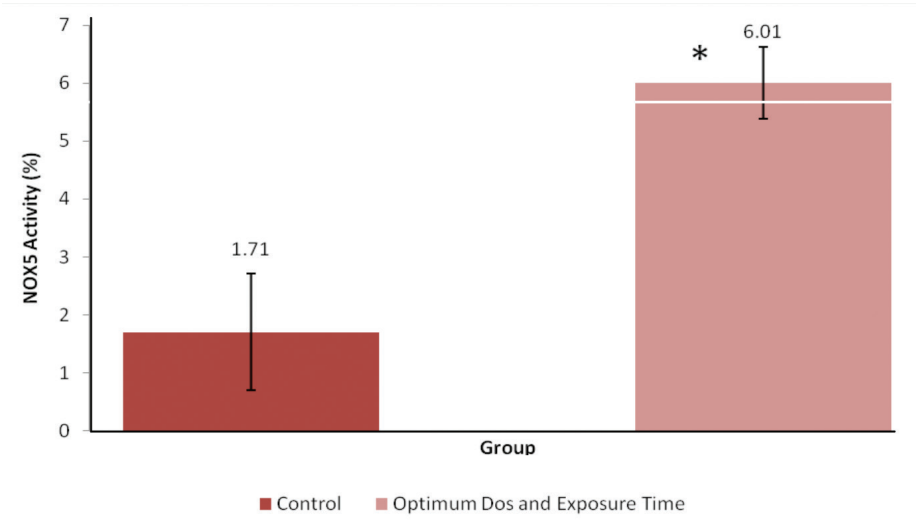

*showed significant different with control group $(p<0.01)$, where $n=8$

FIGURE 1. Optimal frequency and time of exposure towards NADPH oxidase 5

(NOX5) NOX5 activity $\mathrm{t}(1598)=-102.195, p<0.01$

RF-EMW exposure. We suspect the magnetic effect of the test smart phone had caused phospholipid peroxidation of plasma membrane and mitochondrial membrane (Avendano et al. 2012). Furthermore, increase of total ROS compared to antioxidant had also possibly contributed to elevated phospholipid peroxidation activity. All these had led to significant sperm damage (Verachi \& Vasan 2012). Decreased sperm concentration is likely caused by apoptosis. Similar study was seen by Liu et al. (2015) and Shokri et al. (2015) that showed the chronic exposure to RF-EMW ( $2 \mathrm{~h}$ /day, 50 days) will result in elevated apoptotic cell population. 
Testes is an organ that is very sensitive to RF-EMW. This is mainly because of the presence of high fatty acid metabolism within the organ (Sæther et al. 2007). As peroxidation is more likely to occur in organs with high fatty acids, we suspect that RF-EMW had probably induced extensive production of ROS, thus in turn disrupting the restructuring process of sperm membrane molecules. This further had impaired the overall process of sperm maturation (Akbari \& Jelodar 2013). Shahin et al. (2014) had similar results in which their study saw significant reduction in diameter and injury to the testes after RF-EMW exposure of $2 \mathrm{~h} /$ day for 30 days.

Damage to sperm membrane had likely caused similar damage to sperm numerous mitochondrial membrane, resulting in electron leakages from electron transport chain. This would further elevate ROS concentration within sperm. Increase ROS, increases oxidative stress and leads to further damage to various membranes in sperm. Nucleus membrane damage will result in DNA damage and as a consequence a significant reduction in sperm fertilizing capability (Ahmad et al. 2015).

Susceptibility of sperm DNA to damage by ROS is closely dependent on chromatin packaging (Mugunathan et al. 2014). Occasionally, sperm DNA's histone would partially fail to be replaced by protamin thus creating an uncompacted nucleus. This increases chances of histone phosphorylation and separation of DNA strand by Topoisomerase II (Philips et al . 2009). We suspect RF-EMW had effected these parameters, thereby triggering changes in sperm membranes which will further damage the sperm and eventually lead to a permanent DNA damage.

Despite a conclusive association between RF-EMW and sperm parameters, past studies had reported an inconclusive result. Their study had not seen any significant effect on sperm parameter directly but noted an abnormal number of sperm clumping (Yan et al. 2007). The study attributed this observation to an increase of binding protein on sperm surface. We postulate that the result observed had likely occurred as RF-EMW frequency used in their study was much lower than what was used in this study.

Further analysis to the results clearly indicated that sperm concentration, viability and severe DNA damage had only started to decrease after $4 \mathrm{~h}$ continuous exposure with an optimal frequency. Thus, we postulate that although the exposure time is acute (14 days), the frequency (4200 MHz) was sufficiently powerful to disrupt normal sperm parameters. Possibly, similar effects would be seen when using lower frequency but with a longer exposure time.

Previous studies had mentioned possible unspecified NOX pathways that could have played a role in ROS production. But in this study due to the specific marker used we were able to suggest that RF-EMW had specifically activated the NOX5 pathway. We noted that NOX5 enzyme activity had increase with the increase of RF-EMW exposure. We propose this theory based on earlier studies by Friedman et al. (2007) where he noted that NOX5 had triggered production of superoxide, a major component of ROS. Similar theory was also supported by Wright et al. (2014), in which they noted that ROS induces NOX5, resulting in sperm membrane structure changes and DNA damage. Based on the evidence in this study and the aforementioned study, we suspect that NOX5 pathway is capable to trigger activation extracellular-signal-regulated kinase (ERK) pathway. As ERK is fully involved in the regulation of meiosis, mitosis and cell differentiation. These disorders result in impaired sperm physiological processes, including the spermatogenesis and maturation process.

\section{CONCLUSION}

Based on the results, we conclude that RF-EMW expected affecting in reduction in sperm concentration, viability and increase DNA damage. However, the severity is frequency and time dependent. This study found that the optimal frequency (4200 MHz) and exposure time (4 h) was strong enough to generate the DNA damage in the rat sperm and may impaired the fertilizing capability through the NOX5 pathway.

\section{REFERENCES}

Agarwal, A., Deepinder, F., Sharma, R.K., Ranga, G. \& Li, J. 2008. Effect of cell phone usage on semen analysis in men attending infertility clinic: An observational study. Fertility and Sterility 89(1): 124-128.

Ahmad, M., Ahmad, N., Riaz, A. \& Anzar, M. 2015. Sperm survival kinetics in different types of bull semen: Progressive motility, plasma membrane integrity, acrosomal status and reactive oxygen species generation. Reproduction, Fertility \& Development 27(5): 784-793.

Avendano, C., Mata, A., Sanchez Sarmiento, C.A. \& Doncel, G.F. 2012. Use of laptop computers connected to internet through wi-fi decreases human sperm motility and increases sperm DNA fragmentation. Fertility and Sterility 97(1): 39-45.

De Iuliis, G.N., Newey, R.J., King, B.V. \& Aitken, R.J. 2009. Mobile phone radiation induces reactive oxygen species production and DNA damage in human spermatozoa in vitro. PLoS One 4(7): e6446.

Dkhil, M.A., Danfour, M.A. \& Al-Quraishy, S. 2011. Sperm function is affected by the electromagnetic radiation emitted by mobile phone. Afr. J. Microbiol. Res. 5: 4896-4900.

Falzone, N., Huyser, C., Becker, P., Leszczynski, D. \& Franken, D.R. 2011. The effect of pulsed 900-MHz GSM mobile phone radiation on the acrosome reaction, head morphometry and zona binding of human spermatozoa. International Journal of Andrology 34(1): 20-26.

Friedman, J., Kraus, S., Hauptman, Y., Schiff, Y. \& Seger, R. 2007. Mechanism of short term extracellular-signalregulated-kinase activation by electromagnetic field at mobile phone frequencies. Biochem.J. 405(3): 559-568.

Ghani, E., Keshtgar, S., Habibagahi, M., Ghannadi, A. \& Kazeroni, M. 2012. Expression of NOX5 in human teratozoospermia compared to normozoospermia. Andrologia 45(5): 351-356.

IEEE. 2006. Specific Absorption Rate, or SAR - FCC Cell Phone Radiation Exposure Limits. Institute of Electrical and Electronics Engineers USA. https://www.rfsafe.com/ 
Liu, Q., Si, T., Xu, X., Liang, F., Wang, L. \& Pan, S. 2015. Electromagnetic radiation at $900 \mathrm{Mhz}$ induces sperm apoptosis through $\mathrm{Bcl}-2$, bax and caspase-3 signaling pathways in rats. Reproductive Health 12(1): 65.

Meo, S.A., Arif, M., Rashied, S., Khan, M., Vohra, M., Usmani, A., Imran, M. \& Al-Drees, A. 2011. Hypospermatogenesis and spermatozoa maturation arrest in rats induced by mobile phone radiation. J. Coll. Physicians Surg. Pak. 21(5): 262265.

Phillips, J., Singh, N. \& Lai, H. 2009. Electromagnetic fields and DNA damage. Pathophysiology 16(2): 79-88.

Sæther, T., Tran, T.N., Rootwelt, H., Grav, H.J., Christophersen, B.O. \& Haugen, T.B. 2007. Essential fatty acid deficiency induces fatty acid desaturase expression in rat epididymis, but not in testis. Reproduction 133(2): 467-477.

Shahin, S., Mishra, V., Singh, S. \& Chaturvedi, C. 2014. 2.45$\mathrm{GHz}$ microwave irradiation adversely affects reproductive function in male mouse, Mus Musculus by inducing oxidative and nitrosative stress. Free Radical Research 48(5): 511-525.

Shokri, S., Soltani, A., Kazemi, M., Sardari, D. \& Mofrad, F.B. 2015. Effects of wi-fi (2.45 Ghz) exposure on apoptosis, sperm parameters and testicular histomorphometry in rats: A time course study. Cell Journal (Yakhteh) 17(2): 322-331.
Veerachari, S.B. \& Vasan, S.S. 2012. Mobile phone electromagnetic waves and its effect on human ejaculated semen: An in vitro study. International Journal of Infertility and Fetal Medicine 3(1): 15-21.

Wright, C., Milne, S. \& Leeson, H. 2014. Sperm DNA damage caused by oxidative stress: Modifiable clinical, lifestyle and nutritional factors in male infertility. Reproductive Biomedicine Online 28(6): 684-703.

Yan, J.G., Agresti, M., Bruce, T., Yan, Y.H., Granlund, A. \& Matloub, H.S. 2007. Effects of cellular phone emissions on sperm motility in rats. Fertility and Sterility 88(4): 957-964.

Department of Physiology, Faculty of Medicine

Universiti Kebangsaan Malaysia

Jalan Yaacob Latiff, 56000 Cheras

Kuala Lumpur, Wilayah Persekutuan

Malaysia

*Corresponding author; email: amihs_nuc@yahoo.com

Received: 19 December 2016

Accepted: 17 March 2017 